\title{
Training for Workers to Meet Current International Integrattion in Vietnam
}

\author{
Nguyen Minh Tri ${ }^{*}$, Le Ba Vuong ${ }^{2}$ \\ ${ }^{1}$ Ho Chi Minh City University of Technology (HUTECH) \\ ${ }^{2}$ Ho Chi Minh City University of Culture \\ *Correspondence to: Nguyen Minh Tri, Politics and National Defense Education Center, Ho Chi Minh City University of \\ Technology (HUTECH), 475A Dien Bien Phu Street, Ward 25, BinhThanh District, Ho Chi Minh City, Vietnam, E-mail: \\ nm.tri@ hutech.edu.vn Tel: +84-903320779
}

\begin{abstract}
Vocational training for employees is one of the important tasks in order to create a human resource capable of adapting to the rapid changes of the labor market, meeting the requirements of international integration part of rapid and sustainable development of the country. In the process of international integration, technology training for workers in Vietnam has always been the concern of the Government, not only thriving in both size and quality to meet growth but also create sustainable jobs firmly, contributing to ensuring social security for employees in the new context. However, in the integration process and in the context of the industrial revolution 4.0, vocational training for Vietnamese workers is faced with challenges such as quality not meeting the requirements of socio-economic development. Therefore, it is necessary to have a system of solutions to contribute to vocational training institutions to improve the quality of training for workers in the direction of approaching regional and world levels.
\end{abstract}

Keywords: Vocational education, Occupational skills, International integration, Vietnam

\section{Introduction}

Referring to the role of intellectual work, the American futurist, Alvin Toffler emphasized: "Money is gone forever, power is lost; it is only human intellect that, when used, it is not only lost but also grows" (Alvin, 1992). Compared with other resources, human resources, with the leading factor being intelligence, have an outstanding advantage of not being depleted if they can be fostered, exploited and used properly; However, other resources, no matter how much, is only a limited factor and can only be effective when combined with human resources effectively.

In the modern world, when moving gradually to an economy based mainly on knowledge, vocational training for employees is one of the ways to create a workforce with skills, knowledge, and energy creative force for socio-economic development. In that context, many countries are recognizing that vocational training for good workers can make a major contribution to making the economy more competitive and developing skills as a companion factor for growth growth in Southeast Asia (Martin \& Roman, 2013).In the process of international integration, the Government of Vietnam has determined: "Developing vocational education is one of the most important tasks contributing to improving the quality of human resources, adapting to rapid changes. rapid labor market, meeting the requirements of the Fourth Industrial Revolution, international integration and sustainable development of the country"; and "improving the quality of vocational education step by step to meet regional and international standards to meet the needs of domestic human resources and integrate with the regional and international labor market" are the only goals and views direction is indicated in (Party Committee, Labor, Invalids and Social Affairs, 2018). The issue of approaching the level of developed countries, approaching the level of ASEAN-4 countries (including 4 countries Singapore, Malaysia, Thailand and the Philippines) was also pointed out: "40 schools approached the level of ASEAN-4 countries" (Period up to 2025), "50 schools approaching the level of ASEAN-4 countries" (period to 2030) and "Vocational education Vietnam reaches advanced level in the ASEAN region "in the Resolution No. 617/NQ/BCSÐ dated December 28, 2018 on continuing to innovate and improve the quality of vocational education until 2021 and orientations to 2030 (Party Committee, Labor, Invalids and Social Affairs, 2018). 
The interest in vocational training for highquality workers has positively contributed to economic restructuring, increased labor productivity, helping Vietnam escape the "middle income trap", each step to ensure the workers' lives. However, vocational training for employees is still limited, challenging and requires a more comprehensive and comprehensive solution system in the coming time. This is also the main content of this article.

\section{Literature Review}

In the book "Challenges and Opportunities for Vocational Skills Development in Asia: Supply, Demand and Unbalanced Changes", the Asian Development Bank makes policy recommendations on national strategies. Asian countries related to vocational education issues are as follows: Skills development as a key pillar in national planning; Reorientation and so on by the Asian education system; Reform of technical and vocational education and training with priority (ie selecting a number of occupations, in certain priority areas); Minimizing skill mismatches through international cooperation ( $\mathrm{Ra} \& \mathrm{Iu}, 2015$ ). At the same time, in economic and industrial transitions, emerging industries and professions require new skills, while many traditional fields shrink or disappear, leaving the necessary skills behind this is an outdated skill. Key questions faced by policy-makers as well as training institutions are: How to equip workers to transition to higher productivity and emerging industries, and how to ensure workers continue to improve their skills to further increase productivity. This shows the important role of retraining, or lifelong learning, and the role of vocational institutions in the current context (Ra \&Liu, 2015).

In addition, the number of institutions providing training services has increased. In this case, the quality attention comes from those who want to be trained, from the entrepreneurs who want to invest in the training of their workers and from those who provide funding. As a result, quality certification schemes are increasingly being used as an accreditation measure in a highly competitive market. Therefore, there is a second path in the use of standards, in this case focusing on quality assurance (Fernando, 1995). This recommendation is also very important for vocational education institutions, it is an indispensable requirement for survival and development in the context of an increasingly demanding and highly demanding labor market amount.

Cristina Martinez-Fernandez and Marcus Powell (2009) point out some issues related to labor skills training as follows: Employers in strategic economic sectors need to commit to developing scientific skills and high-level technology while skill formation in the workplace is regulated by government intervention to ensure minimum standards and long-term investments in strategic areas; The skill development of the workforce requires a conducive environment in which the provision of skills is balanced with the provision of opportunities to use these skills. Since then, the authors have given some recommendations for the ASEAN community: Continue to expand the system of Technical and Vocational Education and Training (TVET) in other countries. ASEAN members are least developed and in some middleincome economies upgrade quality and labor market relevance. Fostering collaboration between the business community and supplier education and training is an effective and feasible way to reduce mismatches between TVET results and job opportunities (Cristina \& Marcus, 2009).

The International Labor Organization (ILO) also recommends that ASEAN countries pay attention to some of the needs for the type of training (labor) that ASEAN businesses need most, especially management and leadership training (29\%), vocational and technical skills (17\%), customer care services $(15 \%)$. Next is marketing, IT ... and finally accounting (6\%). Not only that, the ILO also pointed out that, in this period and in the near future, the ASEAN community will face skills mismatch in highly skilled professions. Statistics in 2014 show that $58.8 \%$ of ASEAN workers (179 million) are working in vulnerable jobs. Vulnerable employment rates in ASEAN are significantly higher when analyzing gender differences, with the proportion of female workers being significantly higher than that of men.

In the research on vocational training (or vocational education) in Vietnam, there are also many publications on vocational training, which 
directly or indirectly refer to the access to international technical standards. Occupational skills, typically: Nguyen Thu Thuy (2018) pointed out 3 groups of breakthrough solutions to improve the quality and efficiency of vocational education: (i) Give full autonomy to TVET institutions; improve the governance capacity of vocational education institutions; (ii) Standardization of quality assurance conditions; (iii) Link vocational education with the labor market, sustainable jobs and social security. Research on the issue of vocational education associated with the market or the response to the labor market (Bui, 2019), or in other words, vocational training should be studied according to the market approach. Based on the law of supply - demand of the market (Nguyen, 2013)... These studies also give recommendations related to the policies of each vocational education institution to meet the needs of the labor market.

\section{Methods}

William Petty (1623 - 1687), who laid the foundations for the classical British political economy, said that labor is the father, land is the mother of all material possessions. And C. Marx wrote: "A machine not used in the process of working is a useless one ... Iron is rusty, wood is rotten ... Living labor has to grasp those things, transform it into life them" (Karl \& Friedrich, 1995). In particular, in today's age, when all natural resources can be exploited increasingly exhaustedly, only human resources are inexhaustible resources and "knowledge is never taken away" (Alvin, 1992), the more important people and workers play a role. So, when talking about the role of employees, V.I. Lenin affirmed: "The leading production force of all humanity is workers, workers (Vladimir, 2005).

When referring to the role of education and training in general, vocational training for employees in particular in socio-economic development, UNESCO General Director, Mr. F. Mayor emphasized: "Education and training is the most fundamental human right, the key, the lever to a better world. The role of education and training is to develop all human potentials and create the prerequisites for realizing human rights, democracy, intellectual cooperation, equality and mutual respect... Therefore, it is necessary to reconcept more fully the role of education and training in human development, national development, and human development in the new age: education is not mere (or mainly) is the accumulation of knowledge which is more important to awaken the great creative potential of each person to make a useful contribution to the development of individuals and communities" (Pham, 2003).

The UNDP Human Development Report (1900) put forth the impressive statement "the true wealth of every nation is its people. And the purpose of development is to create a favorable environment that allows people to enjoy long, healthy and creative lives" and the biggest difference in economic competition before and today is inwhere people are creating a competitive advantage. The decisive weapon of competition in the twenty-first century is the education and skills of workers.

If human resource development is considered the decisive factor for the development of each country, vocational training for workers is the main method, has a decisive role in the training of qualified human resources. High quality is the basis of the human development strategy, social development, because its functions and objectives are to improve human understanding, both in the field of social sciences, self sciences, science and technology, technology; is the development of perfecting skills in applying scientific, technical and technological knowledge to production; is to improve the human spirit, consciousness, personality; is the training of morality, mentality, physical strength and all capacities and qualities of humans, especially the employee. Therefore, today, countries consider vocational training for workers as the factor holding the fundamental position and the driving force to decide socio-economic development; investment in education and training is an investment for the future.

Experience of Japan, a country with unfavorable natural conditions and poor resources, but knows how to promote the role of vocational training in socio-economic development, has a more equitable effect on opportunities to develop and benefit from socio-economic development for all, is a clear demonstration. 
By acquiring, inheriting and developing theories of vocational training for employees together with the review of practical vocational training experiences in Vietnam and other countries around the world, as well as a clear awareness of the role of Vocational training in the process of international integration, Vietnam has identified: "Education and training together with science and technology are the top national policy, the foundation and driving force for industrialization and modernization (Communist Party of Vietnam, 2006); Because "education and training have the mission of improving people's knowledge, developing human resources, fostering talents, making an important contribution to the development of the country, building Vietnamese culture and people. Developing education and training together with science and technology development is the top national policy; investment in education and training is development investment" (Communist Party of Vietnam, 2011).

\section{Results}

\section{The status of vocational training for employees to meet the requirements of international integration}

In the process of international integration, investment in vocational training for workers in Vietnam has positively contributed to the supply of human resources for growth, increasing labor productivity, helping Vietnam escape the "revenue trap average entry". In the recent international integration process, vocational training for employees has undergone many successful innovations. Most vocational schools, especially in key economic and urban areas, have escaped the difficulty in enrollment to begin restructuring, improving the quality of training and increasing the scale. Vocational training is under the increasing impact of international integration and the 4.0 Industrial Revolution. Factors, such as the large and high-standard international market, the free movement of skilled labor in the region, the emergence of unprecedented new professions and occupations, the automation of many production segment, employment pressure on young people, low labor productivity compared to many countries in the region,... have been and will have a direct impact, requiring breakthrough solutions in vocational training, from reforming the legal framework and supporting policies of the State to reforming and international integration in training, improving the quality of vocational teachers and raising awareness of parents and students about apprenticeship roadmap and job opportunities for vocational human resources.

On May 23rd 2014, The Prime Minister issued Decision No. 761 / QD-TTg approving the Project to develop high quality vocational schools until 2020 (Project 761). Accordingly, 45 public schools have been selected to prioritize concentrated and synchronous investment according to the criteria of high-quality schools, capable of training a number of occupations that are advanced in ASEAN countries or internationally recognition. In the period 2014 - 2019, high-quality vocational training has achieved a number of outstanding results:

- Regarding the development of professional skills, in the 2007-2018 period, vocational training for workers with high occupational skills has a very fast growth rate, an average of $11.67 \%$ / year in the college group and 8,54\% / year for the group of universities and above. Meanwhile, the groups without occupational skills and low and middlelevel occupational skills tended to decrease with an average annual rate of $-2.27 \% ;-3.51 \% ;-2.40 \%$. Regarding the structure and vocational training for workers with occupational skills out of the total workforce in 2018, the number with high-level occupational skills (colleges and universities) accounts for $67.87 \%$ (university $39,81 \%$, college $28.06 \%$ ). Meanwhile, the number with low-level occupational skills (elementary) accounts for only $11.46 \%$ and with intermediate vocational skills accounts for $20.66 \%$ (Nguyen, 2020).

- The number of enrollment increases every year. In 2017, the enrollment size increased by nearly two times compared to 2015. From 2018, the enrollment size increased on average from $10 \%$ to $15 \%$. Particularly, high-quality training programs always have enrollment results that exceed the assigned quota. In 2018, the enrollment result was 176,741 students (an increase of 10\% compared to 2017 and accounting for $8 \%$ of the total enrollment in the country). Most graduates have the right 
professional jobs before and shortly after graduation.

- The State has selected 251 professions and trades in 49 key professions and trades at all levels of 45 schools to support investment, of which 154 occupations in 27 international professions and 60 occupations at 18 occupations and occupations at ASEAN regional level and 37 turns in 28 sectors and occupations at national level. The schools have received the transfer of training for 34 international key occupations (12 occupations from Australia, 22 occupations from Germany). The current training scale of the international transfer system is 2,000 students. Graduates will be awarded with Australian or German associate degrees; 682 lecturers were trained synchronously at home and abroad; 45 schools have been assessed by international partners to meet the standards for training organization (Le, 2020).

- The schools meet the quality accreditation standards in the country. In which, 21 schools operate the UK quality management process, 8 international accreditation pilot schools have basically met the standards assessed by British and German experts.

Most corporations and large enterprises have been interested in and directly participating in vocational training, such as Vingroup, Sungroup, FPT, Samsung, MuongThanh, Thaco, FLC... Investment projects with human needs. High quality has been basically met. Cooperation between enterprises and schools has been strengthened in the direction of increasing incompany training, custom training... Most of the high-quality training programs have over 30 incompany training periods $\%$, practice time is over $50 \%$ of the program.

- The schools invested in providing high quality vocational training have the mission of leading, spreading and impacting the whole system while the system needs to focus on developing the quantity and scale of the training. This becomes a big challenge in the context and conditions of Vietnam. According to the World Economic Forum's 2018 Global Competitiveness Report, Vietnam ranked 77/140 in the economy in terms of overall competitiveness and 97 out of 140 on skill pillars (of which, on indicators of the company's investment in staff training and development ranked 81/140, vocational training quality ranked $115 / 140$, university student skills ranked 128/140) (Le, 2020).

With the care to invest in the development of vocational training for workers in the integration process, it has contributed to improving the quality of vocational training in Vietnam, increasing 13 ranks and ranked 102/141 in the country. There has been a positive change in vocational training with $85 \%$ of the people completing the job. More and more effective training models appear. In many vocational schools, $100 \%$ of students after graduation have jobs with high income... (Dan SinhNewspaper, 2019). The results achieved in vocational training for employees in the innovation process have contributed an active part in Vietnam's socio-economic development in the integration process, especially in the economic field. The Economist (UK) magazine in August 2020 ranked Vietnam in the top 16 most successful emerging economies in the world. According to World Bank (WB) data in 2019, with an average economic growth of $6.8 \%$ / year in the 2016 - 2019 period, Vietnam is in the top 10 of the highest growing countries. Although heavily affected by the COVID-19 epidemic, while most economies fell into recession, with the synchronous and drastic direction of "dual goals", Vietnam has maintained growth positive growth is quite good. According to the World Bank, Vietnam's GDP in 2020 is estimated at $2.8 \%$, belonging to the group of countries with high economic growth rates in the region and in the world (The World Bank, 2020).

From being one of the poorest countries in the world, Vietnam has grown rapidly to become a low-middle-income country, with GDP per capita reaching about $\$ 2,800$ in 2019 , more than 45 million people out of poverty; is one of the fastest growing and most dynamic economies in the region. In terms of gross domestic product, Vietnam is the 46th economy in the world. According to the International Monetary Fund (IMF), Vietnam's GDP is now estimated at more than 340 billion USD, surpassing Singapore and Malaysia, ranking fourth in the region (Vietnam Business Insider, 2020). 
The Global Competitiveness Report published by the World Economic Forum, out of 140 countries ranked in 2018, Vietnam is the country with the highest level of competition in the world (transaction economics, 2020). Vietnam has become one of the most open economies in the world (accounting for about 200\% of GDP). In particular, with the participation in new generation free trade agreements (FTAs), it will have a direct impact on the Vietnamese economy, helping Vietnam become a competitive and innovative economy create stronger. Some foreign experts said that Vietnam has the potential to become one of the most prominent economies in Asia, despite the challenges and crisis from the epidemic of acute respiratory infections COVID-19. According to Japanese economist Hamada Kazuyuki, Vietnam has the potential to become a great power in the future (Hamada, 2020).

Although there are important reforms in vocational training and education for employees, there are still many shortcomings:

Firstly, the vocational training and education institutions have not yet ensured that the vocational training and education institutions have strongly shifted towards the development of occupational skills for employees; the operation of vocational training and education institutions does not have a close connection between career orientation and development of professional skills and employment with enterprises. Therefore, employees lack and weaken both the necessary "hard skills" and "soft skills", especially foreign languages, computer skills, teamwork skills, in a multicultural environment...

Second, the institutions for the development of occupational skills have been formed but have not been completed yet and keep pace with the development and change of practice, the management capacity for the development of professional skills is still inadequate. The implementation of managerial and professional skills development functions of state management agencies, such as advising, proposing policies and laws, organizing the development and appraisal of national occupational skill standards,... is limited, has not yet met the requirements of developing a professional and modern system of professional skills; The participation of other subjects, especially enterprises is still under form.

Vietnam's national vocational skill standards are slowly being promulgated; The organization of assessment and certification of occupational skills has not been widely deployed, only meeting a very small part of requirements of the list of occupations and requirements of workers, many key occupations have not yet targeted national vocational skill standards. The promulgated national occupational skill standards are still low compared with regional and international occupational skill standards; the development of occupational skills of employees has not met the needs of users and enterprises, especially when enterprises apply new science and technology from the achievements of the Industrial Revolution 4.0. The national vocational skill assessment and certification institutions have not developed widely, their capacity is still limited (in terms of human resources for assessment, banking of exam questions, application of information technology...), yet meeting the needs of the increasingly demanding reality. According to a recent study by the Institute of Social Labor Science, currently labor productivity in Vietnam and corporate governance skills are very low and currently $2 / 3$ of the employees lack labor skills and skills art; $55 \%$ of enterprises said that it is very difficult to find a source of high quality labor. While over $60 \%$ of FDI enterprises are planning to expand their investment in Vietnam, it is very difficult to attract investment without improving the quality of their labor force (Le, 2019).

Third, the labor market institution, although always being supplemented and completed, has not kept up with the constantly changing and complicated practical situation. In which, the liberation of production and labor power is not ensured; the labor market is not evenly developed and still fragmented; Young people still face many difficulties, even with occupational skills, in freedom of movement by occupation, education level, geographic area, formal / informal sector, by job position, ... due to lack of labor supply and demand forecasts, limited labor market information, employment service provision, and administrative barriers, especially household 
registration, residence, access to basic social services...

Fourth, the labor market service system (analysis, forecasts, labor market information, job services...) supports skilled workers to move in the labor market underdeveloped, especially job exchanges; application of information technology is weak and service quality is not high.

Limitations in vocational training for workers inevitably lead to per capita income in Vietnam today still low middle compared to other countries in the region, only higher than other countries like TimorLeste, Cambodia and Myanmar. Compared with other ASEAN-6 countries, this income level is quite far, only $4.5 \%$ of Singapore, $8.4 \%$ of Brunei, $23 \%$ of Malaysia, $34.2 \%$ of Thailand, $65 \%$ of Indonesia, $79.2 \%$ of the Philippines (VOV, 2020). In the context of the Industrial Revolution 4.0, Vietnam is showing signs of "slowing down" compared to other countries in the region. Vietnam's competitiveness is still low compared to many ASEAN countries. Many exported products of Vietnam have low domestic added value, mainly performing the assembly function. The participation of domestic firms in major global value chains (GVCs) is limited, and exports are mainly driven by the foreign direct investment (FDI) sector accounting for more than $70 \%$ of the total export turnover (Nguyen, 2020). The risk of falling into the middle income trap of Vietnam still exists if Vietnam does not promptly renew its vocational training and increase its growth in the coming time.

Orientation and training solutions for employees to meet integration requirements in the coming period

The State gives priority to investment in highquality and key schools and occupations; schools are highly autonomous and actively associated with businesses in training. Quality accreditation and standardization work are determined to be implemented synchronously, closely following international standards to quickly contribute to improving the quality of training, meeting international integration requirements. Enterprises and private investors are encouraged to participate in high-quality vocational training to meet the needs of enterprises and to supply high-quality human resources for domestic and foreign labor markets. From the above point of view, the basic orientations for vocational training in the coming time are:

Firstly, vocational training reform should focus on both the training size, structure and quality; increased autonomy and accountability for vocational training institutions; inherit and bring into play the achieved achievements, selectively absorb international experiences suitable to Vietnam's socio-economic conditions; standardize vocational training towards international integration; creating a breakthrough in the quality of occupational human resources.

Second, to develop an open, diversified and flexible vocational training system with many training modes and levels to meet the needs of both employees and employers; focusing on lifelong occupational skills to improve labor productivity; closely linking vocational training with the needs of the labor market, taking the acceptance of the labor market as a measure of the effectiveness of vocational training.

Third, diversify investment resources for vocational training, in which the State plays a key role. The State gives priority to focusing on synchronous investment to form high-quality schools; key national industries and occupations, the trades and occupations approaching the regional and international advanced level; to attach importance to developing occupational skills for specific subjects and professions.

Fourth, vocational training reform, creating job opportunities, increasing income and productivity of occupational human resources is a common task of the whole political system and needs to join hands to take on the responsibilities of the authorities state management, training institutions, businesses, press agencies, the media, parents, students and workers.

From the above points of view and orientations, some solutions are proposed to innovate and develop vocational training for employees in the coming time:

Firstly, renewing thinking and raising awareness of the development of professional skills on the basis of young human resources as the center, to 
promote all human resources for sustainable growth and development of the country. From there, highlighting the role and responsibility of the State, employers, training institutions, vocational education institutions, enterprises, social partners and youth themselves for skill development my job.

Second, improve the institution and strongly develop the national vocational skill assessment and certification system in the direction of specialization, professionalism and modernization: Set up a forecasting organization and strengthen the forecasting work. demand for career skills of young people; capacity building and speeding up the addition of the list of jobs requiring a national vocational skill certificate; approach international standards and strengthen international cooperation in vocational training. Formulate and promulgate quality assurance conditions in vocational training towards approaching regional standards of ASEAN4 and developed countries in the G20 group; building a comprehensive, complete and reliable database on vocational training in order to well serve research and statistics related to the quality of vocational training and human resources; to encourage and support pilot vocational training institutions in implementing training programs transferred from abroad to draw experience for mass deployment, creating international-standard human resources for the domestic market and internationally.

Third, to invest in high-quality vocational training institutions and key industries and occupations. In particular, to attach importance to reviewing and arranging public vocational training institutions in the direction of improving operational efficiency and increasing the proportion of training programs according to international standards. Strengthen the forecasting, planning and orientation of vocational training institutions, focusing on industries and occupations with great demand in the coming time, such as information technology, tourism and hotel and agricultural management high-tech industry, healthcare and healthcare...; encourage vocational training institutions to design training programs capable of attracting good and good learners to have quality human resources, contributing to reducing waste of social resources when many learners are good and good college career but must work in contravention of expertise, forte, profession or profession.

Fourth, continue to improve institutions and develop a labor market capable of connecting labor supply - demand to create a level playing field, healthy competition for workers in the direction of continuing to fully release their labor. moving, removing administrative barriers for workers to freely move to space and careers; to develop the labor market widely throughout the country, especially in underdeveloped regions and ethnic minority areas; to step by step develop high-quality human resources market; strongly develop the labor market infrastructure, especially the labor supplydemand forecasting system and labor market information, provide timely and effective support for young people with free skills shifts in the labor market for sustainable employment opportunities.

Fifth, link vocational training with the labor market, sustainable jobs and social security. To promote cooperation between vocational training institutions and job placement centers, job exchanges and job fairs to assist learners in finding jobs after graduation; attach importance to linking training with sending workers abroad; enhance communication, raise people's awareness of vocational training opportunities and roadmap, job opportunities and career roadmap for vocational human resources, contribute to promotion and enrollment for vocational training institutions; continuously update new vocational skills requirements and new vocational recruitment trends, build a portfolio of vocational skills for both present and future as a basis for design, update vocational training programs in accordance with practice; increase information on vocational training programs targeting vulnerable groups, such as ethnic minorities, the poor, out-of-school adolescents, people with disabilities... to create access opportunities apprenticeship and jobs for all subjects in society, so that no one will be left behind in the development process.

Sixthly, to expand international cooperation on career skill development for young people through policies to encourage foreign investment in vocational training and education institutions for youth; cooperation in the development of the national occupational skill assessment and 
certification system; support the computerization of management and administration of the national

\section{Conclusion}

Vocational training for workers in the international integration process is an inevitable trend in Vietnam today. That not only creates a premise for socio-economic development in general, but also continues to promote international integration in the context of the industrial revolution 4.0. In order to accelerate the current international integration process, vocational training institutions need to aim to improve the qualifications, skills and skills of workers to meet regional and international standards, play a decisive role. Therefore, vocational training institutions need to renew their thinking, vigorously renew their goals and methods of implementation, in order to improve their own competitiveness as well as that of the Vietnamese labor market. Policies to support vocational education institutions in Vietnam have shown effectiveness and need to be done more and more quickly to help vocational education institutions to provide goods with higher quality and economic efficiency, meeting the requirements of the fourth industrial revolution which is taking place today.

\section{Acknowledgement}

All authors contributed equally to the conception and design of the study.

\section{References}

1. Alvin, T. (1992). Power Shift. Hanoi, Vietnam: Theoretical Information Publishing House, 41.

2. ASEAN. (2004). ASEAN Policy Blueprint for SME Development (APBSD) 2004-2014, ASEAN.

3. Bui, N. D. (2019). Some theoretical issues about the management of vocational training in vocational colleges to meet the current labor market needs. Journal of Education, Vol. 442, pp. 26-30.

4. Center of WTO and Integration, Chamber of Commerce and Industry of Vietnam. (2017). Building ASEAN occupational skill standards. Retrieved from: http://aecvcci.vn/tin-tuc- vocational skill assessment and certification system...

n1945/xay-dung-tieu-chuan-ky-nang-nghe-

khoiasean.htm

5. Communist Party of Vietnam. (2006). Document of the 10th National Delegate Congress. Hanoi: National politics, 37.

6. Communist Party of Vietnam. (2011). Document of the 11th National Delegate Congress. Hanoi, Vietnam: National politics, 77.

7. Communist Party of Vietnam. (2016). Document of the 12th National Delegation. Hanoi,Vietnam: Central Office of the Communist Party.

8. Cristina, M. F., \& Marcus, P. (2009). Employment and Skills Strategies in Southeast Asia Setting the Scene. OECD, Printed in France. OECD Local Economic and Employment development Programme, LEED Programme.

9. Dan sinh Newspaper. (2019). Quality of vocational training in Vietnam increased 13 ranks, the highest in ASEAN. Retrieved from: https://baodansinh.vn/chat-luong-dao-tao-ngheviet-nam-tang-13-bac-cao-nhat-asean20191016010646359.htm

10. Government. (2019). Decree No. 15/2019 / $N D-C P$ detailing a number of articles and measures to implement the Law on Vocational Education.

11. Fernando, V. Z. (1995). Quality management in Vocational training. The use of standards and their different applications. International Labour Office - InstitutoTécnico de Capacitación y Productividad. Retrieved from: https://www.oitcinterfor.org/sites/default/files/f ile_evento/ref_pap_int2.pdf

12. Ha, A. (2019). Standardize the national vocational skill assessment system. Financial journal. http://tapchitaichinh.vn/nghien-cuutrao-doi/chuan-hoa-he-thong-danh-gia-kynang-nghe-quoc-gia- 316813.html

13. Hamada, K. (2020). Future power: Redrawing the world map in 2030. Hanoi, Vietnam: Publishing House World, 74. 
14. ILO. (2008). Labour and Social Trends in ASEAN 2008: Driving Competitiveness and Prosperity with Decent Work. Bangkok: ISO.

15. Karl, M \& Friedrich, E. (1995). Complete episode, ep.46, part II. Hanoi, Vietnam: National Political, 247.

16. Le, A. (2019).Quality of human resources in Vietnam integration period: Opportunities and challenges. Retrieved from: https://haiphong.gov.vn/Chuyen-de/Nang-caochat-luong-dao-tao-nghe-cho-lao-dong-nongthon/Chat-luong-nguon-nhan-luc-Viet-Namthoi-ky-hoi-nhap-Co-hoi-va-thach-thuc40660.html

17. Le, Q. (2020). Provide high-quality vocational training to meet the requirements of Industrial Revolution 4.0 and integration. Retrieved from: https://www.tapchicongsan.org.vn/web/guest/v an_hoa_xa_hoi/-

/2018/815936/view_content?_contentpublisher _WAR_viettelcmsportlet_urlTitle=dao-taonghe-chat-luong-cao-dap-ung-yeu-cau-hoinhap-va-cach-mang-cong-nghiep-4.0

18. Martin, P., \& Roman. H. (2013). Introduction of a Quality Management System for Vocational Education and Training in Slovakia. International Journal of Engineering Pedagogy, Vol 3, No 3, 18-23.

19. Nhu, M. (2018). World Bank: " $13 \%$ of Vietnam's population is middle class by world standards". Retrieved from: https://vietstock.vn/2018/04/world-bank-13dan-so-viet-nam-thuoc-tang-lop-trung-luutheo-chuan-the-gioi-768-594269.htm

20. Nguyen, P. N. (2007). Higher Education: An Element of Quality. Hanoi, Vietnam: National University, 19.

21. Nguyen, T. T. (2018). Continue to implement Resolution No. 29-NQ/TW on fundamental and comprehensive innovation of vocational education in the coming time. Journal of Propaganda. Retrieved from: http://tuyengiao.vn/khoa-giao/giao-duc/tieptucthuc-hien-nghi-quyet-so-29-nqtw-ve-doimoi-can-ban-toan-dien-giao-duc-nghe-nghieptrong-thoi-gian-toi- 117311

22. Nguyen, H. D. (2020). Developing professional skills to improve the quality and ability to move Vietnamese youth human resources in the labor market. Retrieved from: https://www.tapchicongsan.org.vn/van_hoa_xa _hoi/-/2018/819668/phat-trien-ky-nang-nghenghiep-de-nang-cao-chat-luong-va-kha-nangdich-chuyen-nguon-nhan-luc-thanh-nien-vietnam-tren-thi-truong-laodong.aspx?fbclid=IwAR1guQHPFebhhcGCG XnIOMTtMV5fLdcJTdIWwutA5o_7NJmB8I0 AL7GMEn4

23. Pham, M. H. (2003). About education. Hanoi: House National politics, 19-23.

24. Prime Minister. (2012). Decision No. 630/2012/QD-TTg on Approving the Strategy for Vocational Training Development for the 2011-2020 period.

25. Prime Minister. (2020). Directive 24/CT-TTg, on promoting the development of skilled human resources, contributing to improving labor productivity and increasing national competitiveness in the new situation.

26. Ra, S. B. C., \&Liu.A.(2015). Challenges and opportunities for skills development in Asia: Changing supply, demand, and mismatches. Mandaluyong City. Philippines: Asian Development Bank.

27. The economics of transactions. (2020). Competitiveness rating of Vietnam.Retrieved from:

https://tradingeconomics.com/vietnam/competi tiveness-rank

28. The Party Committee of the Ministry of Labor, War Invalids and Social Affairs. (2018). Resolution No. 7/NQ / BCSĐ dated December 28, 2018 On continuing to innovate and improve the quality of vocational education through 2021 and orientation to 2030.

29. The World Bank. (2020). Overview of Vietnam. Retrieved from: https://www.worldbank.org/vi/country/vietnam /overview

30. Tri, N. M. (2020). Impact of Economic Growth on Social Security in Vietnam. International Journal of Humanities and Social Science. URL: http://dx.doi.org/10.30845/ijhss.v10n3a9

31. Tri, N. M. (2020). Economic growth with poverty reduction in Vietnam. Journal of Critical Reviews, Vol.7, Issue 18, 2020, ISSN: 2394-5125, DOI: 10.31838/jcr.07.18.260 
32. Vladimir, I. L. (2005). Entire episode, ep. 38. Hanoi, Vietnam: National politics, 430.

33. Vietnamese-German Programme Reform of TVET in Viet Nam. (2020). Program "Vietnam Vocational Training Renewal". Retrieved from: https://www.tvetvietnam.org/vi/topic/140.ao-to-ngh-ti-vn.html.

34. Vietnam Business Insider. (2020). IMF: Vietnam's economy has surpassed Singapore and Malaysia. Retrieved from: https://vietnambusinessinsider.vn/imf-nenkinh-te-viet-nam-da-vuot-singapore-malaysia13923.html

35. VOV. (2020). With steady growth, Vietnam is moving towards a new position in ASEAN.Retrieved from: https://vov.vn/kinhte/tang-truong-vung-chac-viet-nam-huong-toivi-the-moi-trong-asean-1076709.vov 